表II-1 紙パルプ工業生産指数

(30年 $=100$ 付加価値ウエイト)

\begin{tabular}{|c|c|c|c|c|}
\hline & 鉱工業総合 & 製造工業 & $\begin{array}{l}\text { 紙パルプ } \\
\text { 工 業 }\end{array}$ \\
\hline \multirow{4}{*}{ 四 } & $\mathrm{W}_{0}$ & 100 & 95 & \\
\hline & $\mathrm{W}_{1}$ & & 100 & $7 \%$ \\
\hline & 31年平均 & 116 & 116 & 117 \\
\hline & $32 \quad \prime \prime$ & 128 & 128 & 141 \\
\hline \multirow{5}{*}{ 国 } & $33 \quad \prime \prime$ & 123 & 124 & 161 \\
\hline & $34 \quad \prime \prime$ & 142 & 144 & 197 \\
\hline & $35 \quad \prime \prime$ & 166 & 168 & 233 \\
\hline & $36 \quad \prime \prime$ & 184 & 187 & 251 \\
\hline & $\begin{array}{c}\text { 年 対 比 } \\
36 / 35 \\
\end{array}$ & (111) & (111) & (108) \\
\hline \multirow{2}{*}{ 全 } & $\mathrm{W}_{0}$ & 100 & 92 & \\
\hline & $\mathrm{W}_{1}$ & & 100 & $4 \%$ \\
\hline 国 & 36年平均 & 277 & 289 & 222 \\
\hline
\end{tabular}

（注）「四国経済概観」37.8.25 四国通産局編 - 四国商工協会発 行による。
（口）原木，チップ事情

第 36 次農林省統計（昭和 34.4.1 現在）に よると，四国の森林蓄積量は全国のそれの $5.3 \%$ に当る。全国森林蓄積量がN $(47 \%)$ よ りも L (53\%) の方が多いのに対して，四国 のそれはこれとは反対に，L $(40 \%)$ よりも $\mathrm{N}(60 \%)$ の方が多い。

昭和 37 年度パルプ材生産量は表 II -3の通 りであるが，これをみると，四国の生産は全 国のそれの $5.4 \%$ に当り，森林蓄積量の対全 国比 $5.3 \%$ とほぼ見合っている。

パルプ材としての原木とチップの生産割合 は 63 対 37 で，全国，四国ともに同じ生産割 合であるが，NL別でみた場合，原木は全国 がN Lほぼ同じ生産割合であるに対し，四国 はLが断然多く，Nの 2 倍以上を生産してい

表 II -2

36年度四国県別紙パルプ工業生産指数

(30年 $=100$ 付加価値ウエイト)

\begin{tabular}{|c|c|c|c|c|c|c|c|c|c|c|c|c|}
\hline & 德 & 島 & 香 & 川 & 愛 & 媛 & 高 & 知 & 四 & 国 & 全 & 国 \\
\hline & W & 指 数 & $\mathrm{W}$ & 指 数 & $\mathrm{W}$ & 指 数 & W & 指 数 & $\mathrm{W}$ & 指 数 & W & 指 数 \\
\hline $\begin{array}{l}\text { 製 造 工 業 } \\
\text { 紙パルプエフ業 }\end{array}$ & $\begin{array}{l}100 \\
6 \%\end{array}$ & $\begin{array}{r}287 \\
2,113\end{array}$ & $\begin{array}{c}100 \\
6 \%\end{array}$ & $\begin{array}{l}156 \\
169\end{array}$ & 100 & $\begin{array}{l}183 \\
241\end{array}$ & 100 & $\begin{array}{l}204 \\
232\end{array}$ & $\begin{array}{l}100 \\
7 \%\end{array}$ & $\begin{array}{l}187 \\
251\end{array}$ & 100 & 289 \\
\hline
\end{tabular}

（注）「四国経佩概観」 37. 8. 25 四国通産局編，四国商工協会発行による。

る。一方チップは全国，四国ともにLよりも

Nが多い。

四国パルプ材生産量 76 万 $\mathrm{m}^{3}$ のうち, 約 6 割が四国内で消費され，残りの 4 割が四国外

（中国 2 割，九州 1 割，近畿 1 割）へ流出し ている。一方，四国外(主として九州，中国) からは，四国パルプ材生産量の約 3 割に当る 量が流入して来ている。結局, 四国全体とし てはパルプ材生産量の 1 割強 ( $11.11 \% \%$ )
が四国外へ出て行ってしまって，戻って来な い事になっている。

(ケ) 紙パルプ生産高敊よび品種別生産構成 (a) パルプ

四国のパルプ生産高は表 II -4の通りで, 品種別生産構成を 37 年度でみると，全国の それと大体似かよっているが，四国には SP， CGP が少くて KP が多い。対全国比では $\operatorname{AP}$ が $49 \%$ と約半分を占めているのが 目立

表 II-3

37 年度パルプ材生 産量

(単位: $1,000 \mathrm{~m}^{3}$ )

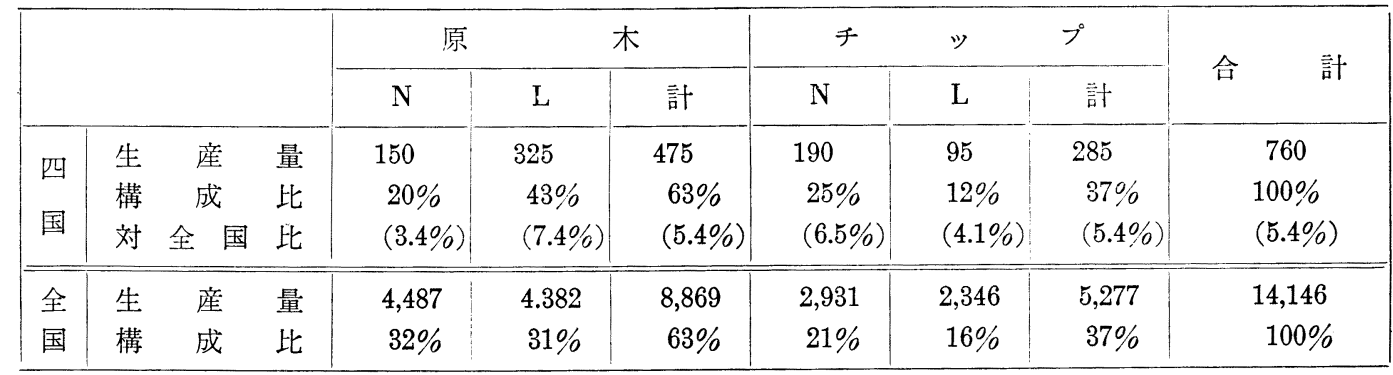

（注）紙パルプ連合会木材部資料汇よる。 


\begin{tabular}{|c|c|c|c|c|c|c|c|c|c|c|c|c|c|c|}
\hline & \multicolumn{4}{|c|}{ 四 } & \multicolumn{5}{|c|}{ 国 } & \multirow{3}{*}{\multicolumn{2}{|c|}{$\begin{array}{l}\text { 全 国 } \\
37 \text { 年 }\end{array}$}} & \multirow{3}{*}{ 対全国比 } \\
\hline & & & \multirow{2}{*}{35 年 } & \multirow{2}{*}{36 年 } & \multicolumn{7}{|c|}{37 年 } & & & \\
\hline & & & & & \multicolumn{2}{|c|}{ 四県合計 } & 徳 島 & 香 川 & \multirow[t]{2}{*}{ 舜媛 } & \multicolumn{2}{|c|}{ 高 知 } & & & \\
\hline $\mathrm{S}$ & & $P$ & 11 & 2 & $2 \%$ & 5 & & & & & 5 & $10 \%$ & 392 & $1 \%$ \\
\hline K & & $P$ & 83 & 146 & 57 & 149 & 74 & & 73 & & 2 & 49 & 1,862 & 8 \\
\hline A & & $P$ & 11 & 11 & 2 & 6 & 1 & 4 & 1 & & & 0 & 12 & 49 \\
\hline$S$ & $\mathrm{C}$ & $\mathrm{P}$ & 25 & 23 & 8 & 20 & & & 20 & & & 6 & 225 & 9 \\
\hline $\mathrm{C}$ & $\mathrm{G}$ & $\mathrm{P}$ & 1 & 10 & 4 & 11 & & & 11 & & & 10 & 384 & 3 \\
\hline G & & $\mathrm{P}$ & 71 & 60 & 26 & 68 & & 7 & 61 & & & 24 & 916 & 8 \\
\hline $\mathrm{T}$ & & $\mathrm{P}$ & 2 & 1 & 1 & 1 & & & 1 & & & 1 & 26 & 4 \\
\hline & 計 & & 204 & 253 & $100 \%$ & 260 & 75 & 11 & 167 & & 7 & $100 \%$ & 3,817 & $7 \%$ \\
\hline
\end{tabular}

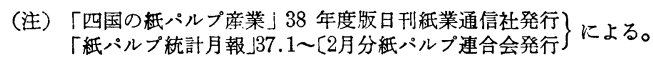

ち, SCP, KP, GP は何れも 1 割弱を占めて いる。さらに, 四国内では徳島の $\mathrm{KP}$, 愛媛 のKP. GP, SCP の多いのが目立っている。 (b) 紙

四国の紙品種別生産高は表 II -5 の通りで ある。品種別生産構成は 37 年度でみると, 洋紙は四国が全体の $52 \%$ で, 全国 $53 \%$ にほ ぼ等しい。板紙は全国が $40 \%$ 近くを占めて いるのに対し，四国ではわずか $18 \% を$ 占め るに過ぎない一方，機械抄き和紙は全国が $8 \%$ を占めるに対し，四国では $30 \%$ も占め ている。つまり四国には和紙が多くて板紙が 少いといらのが特徴である。この事は対全国 比が洋紙 $6 \%$, 板紙 $3 \%$, 和紙 $25 \%$, 紙全 体で $7 \%$ あるあ事をみてもわかる。

これらをさらに分類してみると，まず洋紙 は四国，全国似かよった生産構成であるが， 全国のそれは，新聞巻取紙より印刷用紙の方 が多いが，四国は逆で新聞巻取紙の方が多く なっているのが相異である。

板紙は全国の生産構成がライナー $33 \%$, 中芯原紙 $20 \%$, 白板紙 $21 \%$, 建材原紙 $3 \%$, その他 $23 \%$ とまばらであるのに対し, 四国 の板紙生産構成はライナーが断然多くて, 75 \%を占めており, したがって, 中芯, 白板等 の生産割合が非常に少くなっている。ただ， 建材原紙が全国 $3 \%$ に対し四国 $6 \%$ と多い生 産割合を示している。
四国内では白板紙が香川県でのみ生産され， 白板紙を除く板紙はすべて愛媛県で生産され ている。次に機械抄和紙の品種別生産構成は 全国, 四国ともに塵紙が和紙の半分近くを占 めている。また, 全国では雑種紙のウエイト が大きい。四国和紙生産の対全国比は障子紙 $58 \%$, 塵紙 $26 \%$ ，パルプ紙 $74 \%$ ，仙貨紙 19 $\%$, 薄葉紙 $54 \%$, 雑種紙 $19 \%$, 和紙全体て は $25 \%$ と非常に多い。このように対全国比 において過半数を占めているものが多いにも かかわらず，機械抄和紙全体としては25\% と少くなっているのは, 全国で雑種紙のウェ イトが大さい事によるものである。

$(\Leftrightarrow)$ 電力需給状況

四国の昭和 37 年度電力需要量は 3,791 百万 $\mathrm{kWh}$ で毎年約 $10 \%$ の伸びを示して来たが， 最近, 徳島ならびに東予地区が新産業都市に 指定され，今後はこれらを拠点に産業はます ます発展し，生活水準向上とともに，電力の 使用量も大幅に增大寸る見込であり，この需 要に応ずるため，火力を主体とした電源開発 計画が建てられ（四国電力 $\mathrm{KK} 5$ 力年計画, 火力 50 万 $\mathrm{kW}$. 水力 12 万 $\mathrm{kW}$.計 62 万 $\mathrm{kW}$ ), また 37 年 10 月瀬戸内海を渡るいわゆる「中 四幹線」の完成により中国，九州を含めた広 地域における電気の交流によって，まずは安 定した電力の供給が得られる事となった。

\section{II問題点 今後の発展方策}


紙品種別生夝 量

(単位: 1,000 屯)

\begin{tabular}{|c|c|c|c|c|c|c|c|c|c|c|c|c|}
\hline & \multirow{2}{*}{ 35年 } & \multirow{2}{*}{ 36年 } & \multicolumn{6}{|c|}{37 年 } & \multirow{2}{*}{\multicolumn{2}{|c|}{$\begin{array}{cc}37 & \text { 年 } \\
\text { 全 } & \text { 国 }\end{array}$}} & \multirow{2}{*}{ 対全国比 } \\
\hline & & & & 四 & 国 & 徳島 & 香川 & 愛 媛 & 高知 & & & \\
\hline \multirow{5}{*}{ 洋 } & 新聞巻取紙 & 76 & 65 & $40 \%$ & 78 & & 6 & 27 & & $31 \%$ & 941 & $8 \%$ \\
\hline & 印刷用紙 & 37 & 58 & 30 & 58 & 51 & 0 & 7 & & 34 & 1,017 & 6 \\
\hline & 筆記図画 & 7 & 12 & 6 & 11 & 7 & & 4 & & 3 & 84 & 13 \\
\hline & 包 装 紙 & 20 & 22 & 13 & 25 & 5 & & 20 & & 21 & 631 & 4 \\
\hline & 薄 葉 紙 & 0 & 1 & 1 & 1 & 0 & & & 1 & 1 & 41 & 2 \\
\hline \multirow[t]{2}{*}{ 紙 } & 雑 種 紙 & 19 & 19 & 10 & 20 & 4 & & 12 & 4 & 10 & 291 & 7 \\
\hline & 小 計 & 159 & 177 & $\begin{array}{l}100 \\
(52)\end{array}$ & 193 & 67 & 6 & 115 & 5 & $\begin{array}{l}100 \\
(53) \\
\end{array}$ & 3,005 & 6 \\
\hline \multirow{4}{*}{ 板 } & ライラー & 21 & 46 & 75 & 49 & & & 49 & & $33 \%$ & 733 & 6 \\
\hline & 中芯原紙 & 5 & 6 & 6 & 4 & & & 4 & & 20 & 442 & 1 \\
\hline & 白 板 紙 & 0 & 2 & 10 & 6 & & 6 & & & 21 & 464 & 1 \\
\hline & 建材原紙 & 4 & 4 & 6 & 4 & & & 4 & & 3 & 80 & 5 \\
\hline 紙 & 雑 種 紙 & 1 & 2 & 3 & 2 & & & 2 & & 23 & 508 & 0 \\
\hline 社 & 小 計 & 31 & 60 & $\begin{array}{r}100 \\
(18) \\
\end{array}$ & 65 & & 6 & 59 & & $\begin{array}{l}100 \\
(39) \\
\end{array}$ & 2,227 & 3 \\
\hline \multirow{7}{*}{ 機 } & 障子紙 & 1 & 2 & 2 & 2 & 0 & & 1 & 1 & 1 & 3 & 58 \\
\hline & 塵紙 & 49 & 54 & 48 & 53 & 2 & 19 & 14 & 18 & 47 & 206 & 26 \\
\hline & パルプ 紙 & 7 & 7 & 7 & 8 & 2 & & 6 & 0 & 3 & 11 & 74 \\
\hline & 仙 貨 紙 & 12 & 9 & 10 & 10 & 1 & 0 & 9 & 0 & 12 & 54 & 19 \\
\hline & 薄 葉 紙 & 8 & 8 & 7 & 8 & 0 & & 4 & 4 & 3 & 15 & 54 \\
\hline & 雑 種 紙 & 26 & 28 & 26 & 28 & 4 & & 21 & 3 & 34 & 151 & 19 \\
\hline & 小 & 103 & 108 & $\begin{array}{l}100 \\
(30) \\
\end{array}$ & 109 & 9 & 19 & 55 & 26 & $\begin{array}{l}100 \\
(8)\end{array}$ & 440 & 25 \\
\hline 台 & 計 & 293 & 345 & (100) & 367 & 76 & 31 & 229 & 31 & $(100)$ & 5,672 & $7 \%$ \\
\hline
\end{tabular}

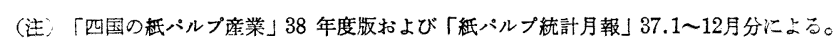

\section{(i) 工業用水の確保}

四国紙パルプ業界最大の問題点は何といっ ても水不足である。全長 $192 \mathrm{~km}$, 年間流量 74 億屯といら吉野川をはじめ，那賀川，肱川， 仁淀川，四万十川など大きい川もあるが，工 業用水としてはあまり開発されていない現状 である。

四国紙生産量の 4 割以上を占める伊予三島, 川之江地区は昔から確固たる用水源がなく， したがって「水争い」も絶えなく，多くの製 紙工場は小さい川や地下水を利用してきた。 しかしながら，川はすぐ枯渴するし，地下水 も水位は低下する一方であったが，昭和 28 年 9 月銅山川の流域変更方式による多目的ダ ムの完成，ならびに貯水池の竣工等により， 18 万屯/日の工業用水を得るに至った。
工業用水確保の過程

(a) 昭和 25.8.14 隧道貫通し銅山川の分水開始。

(b) $\quad 26.3 .23$ 銅山川第四次分水協定調印締結。

(C) $" 28.9 .18$ 銅山川柳瀬ダムの完成。

(d) 28.10 .2 県営三島発電所の完成。

(e) $" 31.8 .17$ 工業用貯水池着工のため伊予三 島, 川之江工業用水組合の設立。

(f) $" 33.10 .1$ 銅山川第五次分水協定調印締結。

(c) $" 33.11 .3$ 工業用貯水池の完成（最大貯水 量 77.353 屯)。

(b) $\quad$ "35. 7.6 銅山川第一発電所発電ルールの 改訂, 工業用水の増量に基つくく伊予三島，川之江 の県内配分協定の調印。

かくて，今日見る紙の町として発展しえた のであるが，これで水不足が解決されたわけ でなく地下水への依存度はまだ高い。この用 水不足の問題を解決するためには「吉野川の 
支流に当る銅山川流域の愛媛県側に降った雨 量分の水を全部愛媛県側で使用する」という いわ何る銅山川完全分水の実現により将来一 層の発展に官民一致努力せねばならぬ。

一方，雨量の多い南四国においても水の問 題がないわけではない。例えば, 高知県下の 二大製紙地带は仁淀川下流にある伊野町と土 佐市高岡町であるが，この掟川の支流であ る面河川に面河ダムを設け，面河からはトン ネル式で道前道後平野の農業, 工業用水とし て利用しょうとする促川上流分水計画（道 前道後総合開発計画）はすでに完成近いが， この淀川上流分水が下流域の伊野町, 高岡 地区製紙業者に影響するといわれている。こ の他, 吉野川, 勝浦川, 鏡川, 加茂川, 国領 川, 那賀川, 奈半利川, 穴内川等の各総合開 発計画がなされているが，四国全体としては 包蔵水力はかなり多く, 昭和 38 年 3 月 31 日 現在, 既開発打よび工事中のもの $36 \%$, 未 開発 $64 \%$ と末開発のものが多い。

要するに四国の水は製紙業のみに限らず， 最近の臨海工業の発展による工業水および電 力需要の增大, また，人口の市部集中化によ る上水道需要の増加, さらに, 農業用水の確 保等, 水の需要は著しく増大しており, 伏流 水, 井戸水の取水も限界に達していると見ら れるため，今後の発展には河川総合開発によ る表流水の最高度の利用が必要である。

(口) 輸送力の増強

四方が海であり, かつ, 起伏の著しい四国 にとっては輸送力の增大こそ経済発展の鍵で ある。道路, 港湾の整備拡充, 四国循環鉄道 と複線化等いろいろあるが，これが完成し， 四国と本州を結ぶ大橋が完成すれば, 京阪神 との陸上交通直続による距離的, 時間的短縮 は製品のコストダウンは勿論, 人的交流も盛 んになり需要は增大する等, 経済領域の拡大 化がなされる。あるいはまた, 四国の産業構 造をも大きく変化させるであろう。

(乡) 技術的教育機関の設置および增強 全国的な問題ではあるが，労働力の不足， したがって人件費の高謄があげられる。特に，
瀬戸内海を隔てて原料資材を搬入，製品を搬 出するといらハンディキャップはこれまで安 い人件費と製品の二次加工, 高級化, 独自性 等によって補って来たものであるからである。

一般に，産業の発展は技術進歩によって左 右されるもので, 少い人件費で効果をより大 きくするためには，技術教育の振與が不可欠 の条件である。すでに製紙試験場等が存在し て，製紙業発展のために寄与しているわけで あるが，最近の技術進歩に適合させるため， より一層の拡充, 研究, 指導が必要であり, また各企業においても職業教育の振興に努め ネばならない。また技術者獲得のためには， 工科の学校が直ぐそこにある事が望委しい。

$\Leftrightarrow$ 地域産業の集団化

近年，地域較差是正の方向として集団化の 傾向が見られるが，四国地方は果してどのよ うな方向を巡っているであろうか。もとより， 製紙業において顕著な発展を認める事が出来 るとしても,さらに経営者間の協同意識に基 づ地域経済の組織化, 拡大化によって, 製 紙業のより一層の発展が期待され得るのだあ る。ここに関連産業の振興, 系列化あるいは コンビナート化の問題が起こってくるのだ市 るが，四国の製紙業をこの見地から見た場合， 均衝のとれた発展をしているとはいえない。 例えば，製紙工場はあっても化学工業が存在 しないなどそれである。

若し，以上のような諸問題が解決されなけ 隹，より以上の発展は望めないのである。

\section{参 考 文 献}

1)「四国経済概観」S 37.8 .25 刊および $\mathrm{S}$ 38. 8.25 刊

四国通産局編，四国商工協会発行

2）「紙パルプ統計月報」S 37.1〜12 月分 紙パルプ連合会発行

3）「年刊四国の紙パルプ産業」S 38 年度版 日刊紙業通信社発行

4）「愛媛県長期経済計画」1962.12 刊 愛媛県総務部企画室編ならびに発行

5）「地域社会の近代化」S 37.3.15 刊 松山商大経済研究所発行 


\section{四国の製紙工業}

\section{ま え がき}

地勢, 気候, 産業等いらいらな面で, 四国 法北四国と南四国に二分される。産業では北 四国があらゆる点で南四国にすぐれているが， その理由としては南四国が大消費地に遠い事, 交通機関が発達していない事，地下資源に乏

しい事，政策上の不備等があげられよう。

四国の主な産業は製銅, 綿業, 紙パルプ工 業, ソーダ, カーバイド, 化繊, 硫安, アル ミ製造業等であるが，紙の生産地は伊予三島 市, 川之江市 (愛媛), 富岡市 (徳島), 伊野 町，士佐市高岡町（高知）である。

製紙業にとって「水」は生命であり，大量 の軟水が要求されるが，島の東西を走る四国 山脈のため, 北四国は雨量が少く, 川は河口 までの距離が短く急流で, しかも，季節的水 量の差が著しく, 工場立地として自然的条件 に恵まれているものではない。逆に, 南四国 には雨が多い。

労働力は豊富で低廉な労働者, 特に優秀な 技術者が必要とされるが，四国地方は一般に 生活程度が低く，乙かも，住民は勤勉であり， 学賃は他地方に比べて低廉であるが，優秀な 技術者となると問題がある。

原料面では, 原木が製品の $2 \sim 4$ 倍の重量 であるのみならず，嵩も大きく，また，生産 コスト中，原木費が 4〜5 割を占めるだけに， 原木の産地ない乙流通地域に位置する事が望 ましいが，北四国はこの点, 瀬戸内海に面し て港湾設備が早くから整い，阪神，中国，九 州方面との海上交通が至便で原料仕入，製品 販売共に恵まれたとはいえないにしても，こ らした海上交通に至便である事が，陸上交通 に比べて運顀が安くてすみ，特に原木輸送に は悪くない立地条件といえよう。

交通機関の発達は原材料仕入, 製品販売,

* 原稿受付 38.12 .18

**大王製紙.三島工場長

\section{塩 野 菊 太 郎**}

さらに労働力の移動をスムーズにさせるが， 四国に和ける陸上交通の開発は非常に僬れて おり，例えば，道路整備，鉄道の複線化など 問題は多い。

要するに，四国の製紙工業としての立地条 件は, 北四国は工業用水に難があり, 南四国 は交通において難があるといえよう。

\section{I. 沿革}

(价伊予紙の沿革

伊予紙の歴史は非常に古く, 奈良時代 (A D. $710 \sim 794$ 年）の租庸調制度にさかの汸り， 為政者の保護の下に発展して来たといわれる が，伊予紙の歴史が判然としているのは，天 正年間（AD. 1573〜1591 年）で宇和郷の豪 族西園寺公広に仕兄ていた土井太郎左衛門と いう侍が，主家の隇亡後，出家して野村林雲 山麓に庵を結び「泉貨」と名乗って，仏道に 励むかたわら楮，三椏を栽培して自家に伝わ る紙を造ったといわれている。その紙は一㣫 の美しい厚紙で，楮を原料とした縦 1 尺5寸, 横 1 尺 1 寸の大きさのもので, 主として帳簿, 経文，折本等に用いられた。

後に，この紙は天和（AD. 1681 年）以後, 泉貨居士の名前にちなんで泉貨紙と呼ばれ， 伊予国の特産物となったが，江戸時代になる とこれが全国に知られ，需要は増し，各地の 製紙地がこれをま社て仙貨, 仙過, 千花とい ら名前をつけて漉きだした。今日いうところ の仙貨紙は昭和 12 年頃, 楮皮の值上りに苦 しんだ産地の者が，マニラ麻を使ってマニラ 仙貨なるものを造り出し, それが戦後, 統制 外の紙を工夫して誰かがこれに仙貨と命名し たのが始りで，泉貨の造り出した紙とは似て

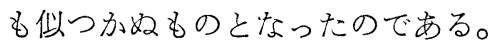

したがって, 伊予紙の発祥地は現在の生産 地たる東予 (伊予三島, 川之江地方) ではな く，南予 (宇和島地方) だったのである。

東予, とくに伊予三島, 川之江地区では天 
保年間（AD. 1830～1848）に山間部落で野生 の楮を原料に，わずかに紙漉きを行なってい た事が確認されるが，伊予の紙が現実に生業 として重視されて来たのは慶応年間（AD. 1865～1868）であって，この時代になると， 今まで農家の片手間仕事でしかなかったこの 業が, 漸く地場産業として芽ばえ, さして特 色ある産業のないこの地にとって，大きな福 音となるに至った。

かくて，明治に入るや紙漉きの伸長テンポ めざましく，あわせて技術面でも

\section{a. 漉き桁の改良}

b. カルキ, 苛性ソーダなど化学薬品による 原料処理の考案

c. 楮, 三椏の原料に麻, ワラパルプの併用

d. ビーターによる「くさ打ち」からの解放

e. 蒸気乾燥機の発明

等，諸々の発明，改良がなされた。

大正に入り，外国から長網抄紙機を輸入す る等，伊予紙は上昇機運に乗ったところで， 第二次大戦に突入したが，戦後，昭和 22 年 和紙一色であったこの地区に，パルプ設備を 併設した洋紙生産が始り，決定的な飛躍態勢 を整え, 昭和 28 年和洋紙の立場は逆となり, あわせて紙加工業の生産もほとんど全分野に 渡って行なわれ出し伊予三島，川之江地区だ けで，四国紙生産高の 6 割を占めるという全 国的にも集約された製紙地区となるに至った。

(口) 土佐紙の沿革

土佐紙の歴史は, 奈良時代の柿本人麿の奨 励説，平安時代の紀貫之による造紙発祥説， 幡多郡一带に残る仙貨紙の祖, 土井太郎左衛 門による説等いろいろとあるが，何れも明白 でない。

慶長 6 年（AD. 1601 年）山内一豊の入国 以来, 彼の土佐紙に対する関心は深く, 漉き 工に対して土地田畑を与光，生活安定を図る 等の保護政策により，土佐紙は発展して行っ たのであるが，彼の秘密主義は徹底していた ため, 紙の種類は限定され，ただ，一部の紙 の品質向上がなされたにすぎなかった。

安芸三郎左衛門の七色紙発明以来, 幾多の
変遷，曲折があったが，その間，製紙技術は 徐々に高揚普及し，地場産業として大きな基 礎作りがなされて行った。

反面，業界の粗製濫造も現出して，明治 29 年高知県令として「紙業取締規則」が公布さ れ，業界有志による紙業組合が創設され，こ こにはっきりと近代産業への足掛りともい光 る産業形態が表面化して, 各種製造組合, 合 資会社，合名会社等が続出して，画期的な機 械抄き和紙の時代入入ったのである。

しかしながら，かかる機械化は当時の手漉 き業者にとって死活問題となり，真剣に討議 されたが，製紙試験場の創設を契機に美術紙， インキ止紙など特殊紙の考案がなされ，ここ に手漉和紙の存続が可能となったのである。

かくて，昭和 35 年度では高知県製造業出 荷額のらち，木材木製品製造業 (18.1\%)，食 料品製造業 (17.5\%) に次いで大きなウェイ ト $(14.6 \%)$ を有するものとなり地場産業と して切り離す事の出来ないものとなっている。

\section{II. 現 況}

(イ）紙パルプ工業の伸び

昭和 36 年度紙 パルプ工業の製造工業に占 める生産割合は，全国 4\%に対し四国 $7 \%$ と 約 2 倍であり，四国内では高知が $18 \%$ と断 然高く，他の三県もまた全国を上迴っている。

一方, 昭和 30 年を基準とした 36 年度紙パ ルプ工業生産指数は, 全国 222 に対し四国 251 と全国を上廻っており，四国内では徳島 の 2,113 が断然高く，香川を除けば何れも全 国を上廻る伸びを示している。

しかしながら，最近の軽工業に代っての重 化学工業の進出は著しく, 例えば 35 年に基準 をおくと 37 年度では，紙パルプ工業の伸び は全国の伸び 122.1 に比べ四国の伸び 122.9 と上名ってはいるものの, 非常に接近したも のとなっており，全国は勿論の事ながら，四 国においても製造工業の伸び（全国 130.1 四 国 123.1）が上記紙パルプ工業の伸びを上廻 る段階に来ている。つまり四国紙パルプ工業 の伸びは 34 年以降は漸減しているのである。

（注）上記生産指数は付加価値額。 